\title{
Adaptation of oralman in the Republic of Kazakhstan as a key factor of the integration in a new community
}

Kamaldinova Aikerim Assylbekovna

Nassimova Gulnar Orlenbaevna

Abdygaliyeva Gulzhan Kanaevna,

Koshigulova Klara Ilyassovna,

Suggested Citation:

Humanites \& Social Sciences.

Global Journal on

Abstract

Kamaldinova Aikerim Assylbekovna, 
1. Introduction

2. Diasporal policy of Kazakhstan after being independent 
3. Adaptation and integration of Oralmans 
Table 1 


\section{References}

"Migration of population"

Politika. Sofiya

Istoriya.

The speech of President. on the Third World Kurultai of Kazakhs. Astana

Data of Statistics agency. 
Global Journal on Humanites \& Social Sciences.

"Migration of population" 